\title{
Kazachstania ichnusensis sp. nov., a diploid homothallic ascomycetous yeast from Sardinian lentisk rhizosphere
}

\author{
Gianluigi Cardinali, Livio Antonielli, Laura Corte, Luca Roscini, \\ Ambra Bagnetti, Cristina Pelliccia and Gianfranco Puddu
}

\begin{abstract}
Correspondence
Gianluigi Cardinali

gianlu@unipg.it
\end{abstract}

\author{
Department of Applied Biology - Microbiology Division, Borgo 20 Giugno, 74, I - 06121 Perugia, \\ Italy
}

\begin{abstract}
During an investigation of yeast biota in the rhizosphere of lentisk in Sardinian semi-arid areas, a strain was isolated that could not be assigned to any known species. The sequence of the D1/D2 domain of the large subunit rDNA gene revealed that the strain belonged to the genus Kazachstania and was phylogenetically related to a clade including Kazachstania aerobia, Kazachstania servazzii, Kazachstania solicola and Kazachstania unispora. The novel isolate differed from members of this clade in its ability to assimilate D-glucono-1,5-lactone and its very weak fermentation of glucose and sucrose; its assimilation profile was unique within the genus Kazachstania. Monosporal colonies were able to sporulate, indicating that the species is homothallic. It is proposed that the isolate represents a novel species, Kazachstania ichnusensis sp. nov., with LCF $1675^{\top}\left(=\mathrm{CBS} 11859^{\top}\right)$ as type strain.
\end{abstract}

Lentisk (Pistacia lentiscus L.) or mastic is a shrub commonly present in semi-arid areas in Sardinia that has the ability to withstand drought and varying salinity conditions (Barazani \& Golan-Goldhirsh, 2009). Yeasts have not previously been observed during studies on the phylloplane of lentisk, although yeasts have been found on the leaves of Mediterranean plants, with a clear prevalence of basidiomycetous species (Inácio et al., 2002, 2010). Both ascomycetous and basidiomycetous yeast have been isolated from the rhizosphere of some plants, including cassava and ginseng (Ferreira et al., 2010; Hong et al., 2006), but no information is currently available on the presence of any yeast in the rhizosphere of lentisk. During an isolation campaign from the rhizosphere of different plants, a yeast strain related to members of the genus Kazachstania was isolated.

The genus Kazachstania was proposed by Zubkova in 1971 with the description of the novel species Kazachstania viticola (Zubkova, 1971), which was then considered to be a synonym of Saccharomyces dairenensis (Von Arx et al., 1977). Naumov et al. (1995) found that the electrophoretic karyotype of $K$. viticola was dissimilar from that of the other $S$. dairenensis strains. Kurtzman \& Robnett (2003) carried out a phylogenetic analysis of the D1/D2 domain of the large subunit rDNA gene, revealing that $K$. viticola belonged to a composite clade including species of the genera Kluyveromyces, Saccharomyces (sensu lato) and Pachyticospora. Due to taxonomic priority,

The GenBank/EMBL/DDBJ accession number for the 26S rDNA sequence of LCF $1675^{\top}$ is HQ616669. the members of the clade were associated with the genus Kazachstania. Since then, novel species of this genus have been found in silage (Lu et al., 2004), wastewater (Wu \& Bai, 2005), natural substrates such as humus and mushrooms (Imanishi et al., 2007), soil of a deciduous forest (Limtong et al., 2007), soil (Chen et al., 2010; Lee et al., 2008, 2009) and Botrytis-affected grape must (Nisiotou \& Nychas, 2008). In general, species of the genus have been isolated from soil and natural or anthropized environments. One species is apparently involved in pathogenicity (Flahou et al., 2010). Classification on the basis of morphological and physiological traits is difficult because there are no distinctive characters (Kurtzman \& Robnett, 2003). Some species are heterothallic (Imanishi et al., 2007), whereas others are homothallic (Nisiotou \& Nychas, 2008).

The novel yeast strain was isolated from soil surrounding lentisk roots. Soil ( $5 \mathrm{~g}$ ) adhering to the roots was scraped off gently with sterile gloves and resuspended in $10 \mathrm{ml}$ physiological solution [aqueous isotonic $0.9 \%$ (w/v) $\mathrm{NaCl}$ solution]. Different dilutions of this suspension were spread onto YEPDA (2\% glucose, $1 \%$ yeast extract, $1 \%$ peptone and $1.7 \%$ agar) containing $50 \mathrm{mg}$ Rose Bengal $\mathrm{l}^{-1}$ and $500 \mathrm{mg}$ chloramphenicol $\mathrm{l}^{-1}$. Forty-seven isolates were selected after visual inspection of the plates and stored prior to study; for storage, isolates were cultured overnight in YEPD (YEPDA without agar) and $1 \mathrm{ml}$ overnight YEPD culture was mixed with $0.5 \mathrm{ml} 50 \%$ sterile glycerol in a $1.7 \mathrm{ml}$ sterile polypropylene tube immediately placed at $-80{ }^{\circ} \mathrm{C}$. All isolates were subsequently grown in YEPD and D1/D2 domain sequencing was carried out as described below. 
Physiological and morphological tests were carried out on the novel isolate in accordance with previously described methods (Kurtzman \& Fell, 1998; Yarrow, 1998).

Cultures of strain LCF $1675^{\mathrm{T}}\left(=\mathrm{CBS} 11859^{\mathrm{T}}\right)$ were grown both on McClary's acetate agar $\left(5\right.$ days at $25^{\circ} \mathrm{C}$ ) and on YEPDA (for 1-2 days at $25{ }^{\circ} \mathrm{C}$ ) and then daily examined microscopically for 1 week for the presence of ascospores.

To induce sporulation of the culture maintained in YEPDA, cells were grown for 2 days in yeast nitrogen base (Sacco) medium containing $2 \%$ glycerol, with shaking at 150 r.p.m. at $25{ }^{\circ} \mathrm{C}$. For short-term storage, the strain was maintained in YEPDA, but for long-term storage, $1 \mathrm{ml}$ fresh overnight culture was frozen with $0.5 \mathrm{ml}$ sterile $50 \%$ glycerol at $-80{ }^{\circ} \mathrm{C}$.

Genomic DNA was extracted and sequenced from all 47 isolates (Bolano et al., 2001; Cardinali et al., 2001). Amplification of the D1/D2 domain of the 26S rDNA was performed using primers NL-1 (5'-GCATATCAATAAGCGGAGGAAAAG) and NL-4 (5'-GGTCCGTGTTTCAAGACGG) (O'Donnell, 1993) with EuroTaq enzyme (EuroClone) and a PTC-100 Peltier Thermal Cycler (MJ Research) according to the following procedure [adapted from the original of Kurtzman \& Robnett (1998)]: initial denaturation at $95{ }^{\circ} \mathrm{C}$ for $4 \mathrm{~min}, 35$ amplification cycles
(94 ${ }^{\circ} \mathrm{C}$ for $1 \mathrm{~min}, 53{ }^{\circ} \mathrm{C}$ for $1 \mathrm{~min}$ and $72{ }^{\circ} \mathrm{C}$ for $1 \mathrm{~min}$ ) and final extension at $72{ }^{\circ} \mathrm{C}$ for $10 \mathrm{~min}$. Amplicons were purified with a GFX PCR DNA purification kit (GE Healthcare) and electrophoresis was performed on agarose gels at $1.5 \%$ (Gellyphor; EuroClone). Sequence data were processed with Geneious (Drummond et al., 2009). Alignment of the D1/ D2 domain of the rDNA sequence was carried out using Muscle (Edgar, 2004). Phylogenetic analysis was conducted in MEGA4 (Tamura et al., 2007).

Strain CBS $11859^{\mathrm{T}}$ exhibited vigorous sporulation on YEPDA medium ( $2 \%$ glucose) after 4 days at $25{ }^{\circ} \mathrm{C}$. After three passages on glucose-containing medium, this ability was strongly reduced and eventually lost. Growth for 3 days on glycerol-containing medium partially restored the ability to sporulate on glucose, although only $20 \%$ of the cells sporulated, rather than $90 \%$ as observed with fresh cultures. Yeast cultures were frozen at $-80{ }^{\circ} \mathrm{C}$ in $17 \%$ glycerol immediately upon isolation; cultures revitalized from frozen samples exhibited high sporulation ability, which was comparable to that of fresh cultures.

In order to test the possibility that this strain is homothallic, eight spores from two different asci were dissected and grown on YEPDA medium until visible colonies were obtained. All cultures transferred onto MacClary's medium

Table 1. Comparison of the assimilation and fermentation profiles of selected substrates by $K$. ichnusensis and related Kazachstania species

Strains: 1 , K. ichnusensis LCF $1675^{\mathrm{T}}\left(=\right.$ CBS $\left.11859^{\mathrm{T}}\right) ; 2$, K. aerobia CBS $9918^{\mathrm{T}} ; 3$, K. solicola CBS $6904^{\mathrm{T}} ; 4$, K. servazzii CBS $4311^{\mathrm{T}}$; 5, K. unispora CBS $398^{\mathrm{T}}$; 6, K. siamensis CBS $10361^{\mathrm{T}}$; 7, K. aquatica CBS $10102^{\mathrm{T}}$; 8, K. africana CBS $2517^{\mathrm{T}}$; 9, K. barnettii CBS $5648^{\mathrm{T}}$; 10, K. exigua CBS $379^{\mathrm{T}}$; 11 , K. yakushimaensis CBS $8388^{\mathrm{T}}$; 12, K. naganishii CBS $8797^{\mathrm{T}}$; 13, K. gamospora CBS $10328^{\mathrm{T}}$; 14, K. zonata CBS $10326^{\mathrm{T}}$; 15, K. pintolopesii CBS $2985^{\mathrm{T}}$; 16 , K. hellenica CBS $10706^{\mathrm{T}}$. +, Growth; -, no growth; w, weak growth; d, delayed growth; ND, not determined. Data for the novel isolate were from this study; all other data were from the CBS database except where marked.

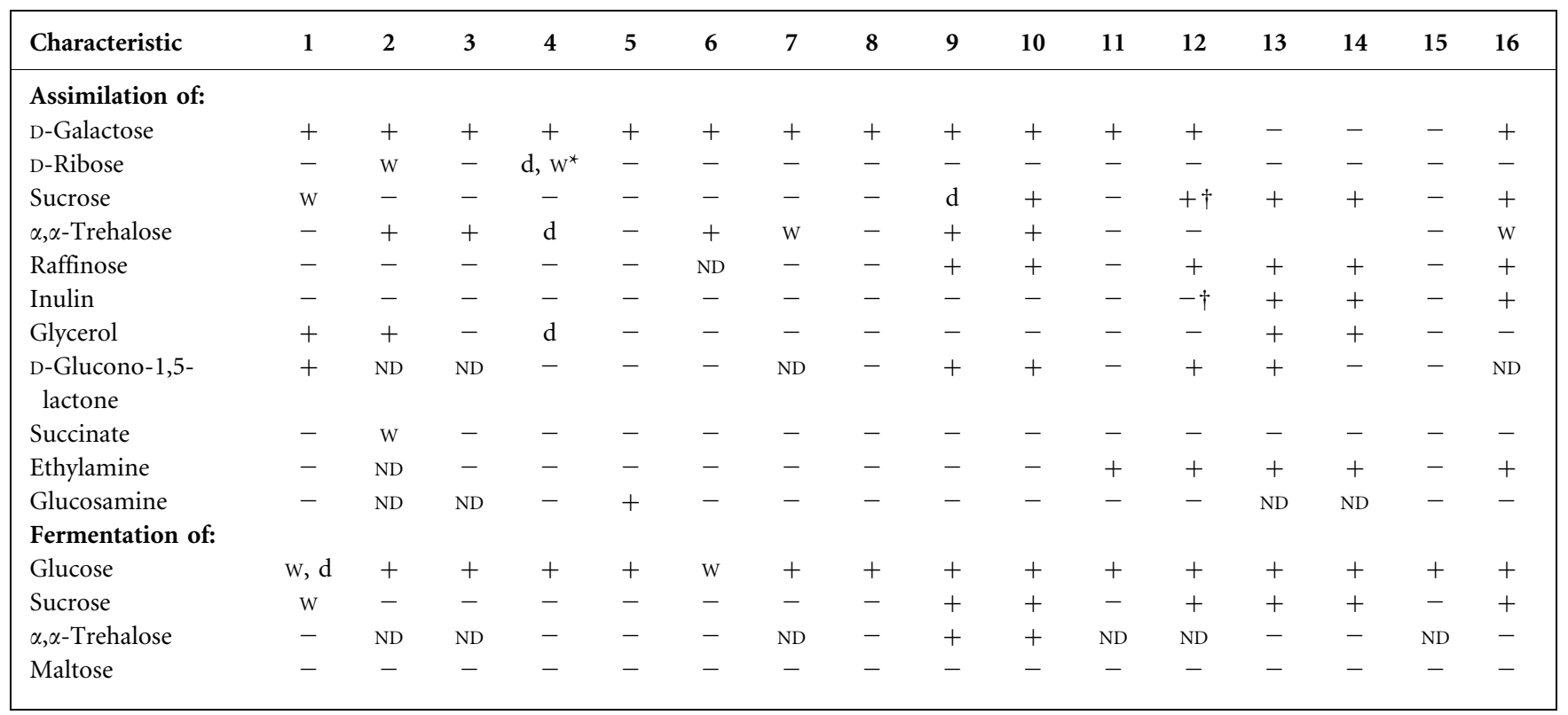

${ }^{*}$ Data from Wu \& Bai (2005).

$\dagger$ Data from Mikata et al. (2001). 

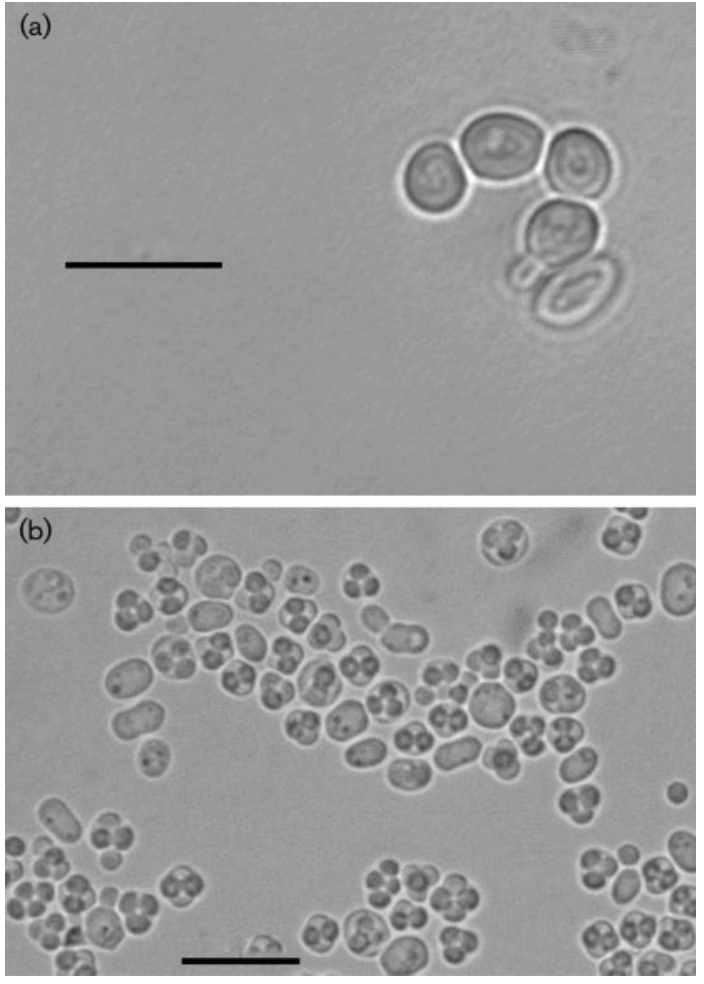

Fig. 1. Microscopic images of $K$. ichnusensis CBS $11859^{\top}$ during two different stages of the growth cycle: (a) actively growing culture; (b) spores on McClary's acetate agar after 5 days at $25{ }^{\circ} \mathrm{C}$. Bars, $10 \mu \mathrm{m}$.

exhibited the ability to sporulate again, indicating that cells of different mating types were formed within the colonies derived from single spores.

The sequence of the D1/D2 domain of the LSU rDNA showed that strain CBS $11859^{\mathrm{T}}$ is related, although with moderate bootstrap support (79\%), to a clade including Kazachstania solicola, Kazachstania aerobia, Kazachstania servazzi and Kazachstania unispora. The moderate level of bootstrap support is shared by other clades within the genus (Fig. 2) and is confirmed by previous phylogenetic reconstructions using the $18 \mathrm{~S}$ rRNA gene (Imanishi et al., 2007), whereas higher bootstrap values were obtained by combining the D1/D2 and the $18 \mathrm{~S}$ rDNA sequences (Chen et al., 2010). The use of different algorithms to reconstruct dendrograms resulted in the same topological relations between strain CBS $11859^{\mathrm{T}}$ and the four species of this clade (data not shown). According to a pairwise comparison, the D1/D2 domain sequences of $K$. ichnusensis displayed nine mismatches $(1.67 \%)$ from the above species and 10 $(1.85 \%)$ from K. servazzii, which exceeds the difference of $1 \%$ suggested as a minimum threshold between species (Kurtzman \& Robnett, 1998) and is much larger than many differences observed among members of this genus (Fig. 2).

On the basis of the rDNA distances, we regard strain LCF $1675^{\mathrm{T}}\left(=\mathrm{CBS} 11859^{\mathrm{T}}\right)$ as a novel species of the genus
Kazachstania and propose the name Kazachstania ichnusensis sp. nov. This novel species status is corroborated by evidence from the assimilation profile of $K$. ichnusensis, which is unique in the genus and differs from those of the four most closely related species, $K$. solicola, K. aerobia, $K$. servazzi and $K$. unispora, by the ability to assimilate D-glucono-1,5-lactone vigorously and to assimilate and ferment sucrose weakly. More importantly, the isolate showed weak fermentation of glucose, whereas it was unable to ferment trehalose or maltose. This fermentation behaviour is similar to that of $K$. siamensis, a yeast isolated from soil (Limtong et al., 2007), and contrasts with the general ability displayed by the members of this genus to ferment glucose vigorously (Table 1). The species has been described on the basis of a single strain, as done previously for some members of the genus ( $\mathrm{Wu} \&$ Bai, 2005), but nevertheless, its description should favour the search for other novel strains.

The novel isolate was the only hemiascomycetous yeast isolated from the lentisk rhizosphere in this study, whereas the other isolates belonged to the basidiomycetous species Cryptococcus festucosus, Cryptococcus phenolicus, Cryptococcus terreus, Cryptococcus terrestris, Cryptococcus uzbekistanensis and Filobasidium globisporum. The newly proposed species is one of the few isolated from rhizosphere, e.g. Kazachstania piceae (Weber et al., 1992) and Kazachstania zonata (Imanishi et al., 2007), whereas most of the other members of the genus were isolated from soil, e.g. K. servazzii (Capriotti, 1967) and K. solicola (Wu \& Bai, 2005).

\section{Latin diagnosis of Kazachstania ichnusensis sp. nov.}

In medio liquido cum glucoso et peptono et extracto levidino post dies 3 ad $25^{\circ} \mathrm{C}$, cellulae ovoideae $(4-5 \times 2-3 \mu \mathrm{m})$, singulae aut binae, per gemmationem reproducentes. Post dies decem sedimentum formatur. Cultura, in agaro cum glucoso et peptono et extracto levidino post dies 7 ad $25{ }^{\circ} \mathrm{C}$, exhibet rotundas et parvas colonias, cum nitido margine et albo opaco colore. In agaro farinae Zea mays post dies 10 ad $25^{\circ} \mathrm{C}$, mycelium et pseudomycelium non formantur. Asci per transformationem cellularum vegetativarum diploidearum, 1-4 ascosporae continentes stabiles sunt. Ascosporae rotundae $(2-3 \mu \mathrm{m})$ possunt videri. Glucosum et sucrosum infirme fermentantur. Glucosum, galactosum, glycerolum et Dglucono-1,5-lactonum assimilantur. Sucrosum, acidum DLlacticum, D-ribosum, maltosum, methyl $\alpha$-D-glucosidum, salicinum, acidum 2-keto-D-gluconicum, acidum D-glucuronicum, acidum succinicum, i-inositolum, acidum citricum et $N$-acetylglucosaminum infirme assimilantur. $\alpha, \alpha$-Trehalosum, raffinosum, L-sorbosum, D-glucosaminum, D-xylosum, Larabinosum, D-arabinosum, L-rhamnosum, cellobiosum, melibiosum, lactosum, melezitosum, inulinum, amylum, erythritolum, adonitolum, dulcitolum, D-mannitolum, D-sorbitolum, acidum malicum, methanolum, ethanolum, kalium nitrosum, kalium nitricum, ethylaminum et L-lysinum non assimilantur. Crescere potest in $0.1 \%$ cycloheximido. Non crescit in substrato 


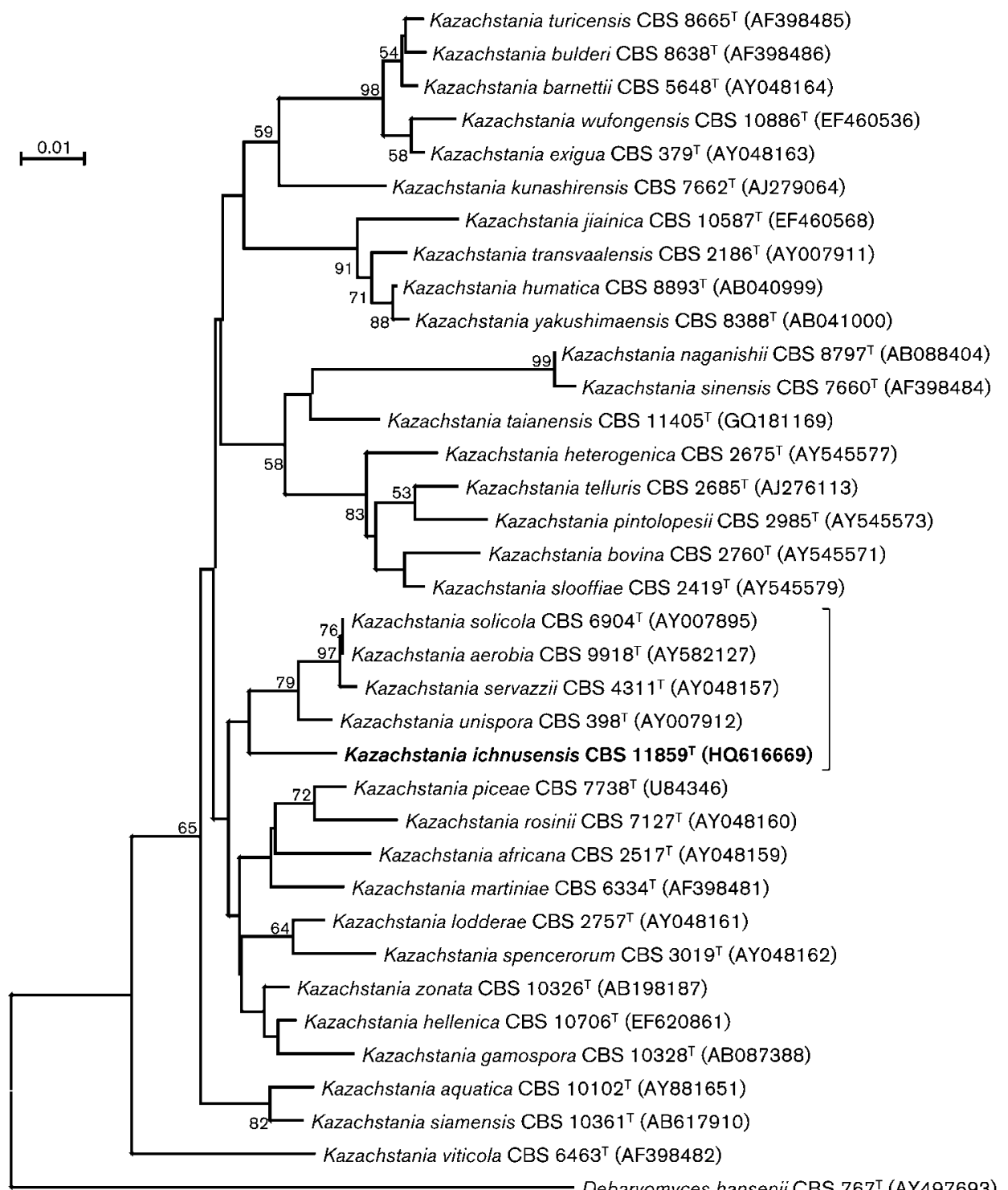

Fig. 2. Phylogenetic tree reconstructed from neighbour-joining analysis (Tamura et al., 2004) of the 26S rDNA D1/D2 domain sequences, computed using the Tamura-Nei method (Tamura \& Nei, 1993), depicting the relationship of strain CBS $11859^{\top}$ with members of closely related taxa. Bootstrap values over $50 \%$ (10000 bootstrap replicates) are shown (Felsenstein, 1985). Reference sequences, all from type strains of the species included in the tree, were retrieved from GenBank and CBS under the accession numbers indicated. The square bracket indicates the subclade containing the novel isolate. Bar, 0.01 substitutions per nucleotide position.

$10 \%$ sal/2\% glucosum continente. Non crescit in $50 \%$ glucosum medio. In $4{ }^{\circ} \mathrm{C}$ et $25{ }^{\circ} \mathrm{C}$ crescere potest, sed non in $37{ }^{\circ} \mathrm{C}$ et $42{ }^{\circ} \mathrm{C}$. Materia amyloidae iodophila non formatur. Ureum non hydrolysatur. Diazonium caeruleum B negativum est. Proteinae, sed non lipides, hydrolisantur.

Typus ex tellure radicum Pistaciae lentisci in Sardinia insula isolatus est et in collectione zymotica Centraalbureau voor Schimmelcultures, Utrecht, sub no. CBS $11859^{\mathrm{T}}$ [in nostro laboratorio LCF $1675^{\mathrm{T}}$ appellatus] depositus est.

\section{Description of Kazachstania ichnusensis sp. nov.}

Kazachstania ichnusensis (ich.nu.sen'sis. N.L. fem. adj. ichnusensis of or belonging to Ichnusa, the ancient name of the island of Sardinia where the yeast was isolated).

After growth in YM broth at $25^{\circ} \mathrm{C}$ for 3 days, cells are ovoid $(4-5 \times 2-3 \mu \mathrm{m})$ (Fig. 1a), and occur singly or in pairs (Fig. 1a). Vegetative reproduction occurs by multilateral budding. Sediment is present. After 7 days at $25{ }^{\circ} \mathrm{C}$ 
on YM agar, streak cultures present small, round-shaped colonies with sharp edges, and a colour varying from matt to bright white. On Dalmau slide cultures with corn meal agar or rice extract agar after 10 days at $25{ }^{\circ} \mathrm{C}$, pseudomycelium or true mycelium is not formed either under the cover glass or without cover glass. Sporulation occurs abundantly on YEPDA and McClary's acetate agar at $25^{\circ} \mathrm{C}$ after 4 days. Diploid cells are transformed directly into asci containing four round ascospores $(2-3 \mu \mathrm{m})$. Ascospores are not liberated from asci after 1 month at $25{ }^{\circ} \mathrm{C}$ (Fig. 1b). Glucose and sucrose are fermented weakly. Glucose, galactose, glycerol and D-glucono-1,5-lactone are assimilated. Other carbon compounds tested in this study, including sucrose, DL-lactate, D-ribose, maltose, methyl $\alpha$ D-glucoside, salicin, 2-keto-D-gluconate, D-glucuronate, succinate, citrate, $i$-inositol and $N$-acetylglucosamine are weakly assimilated. $\alpha, \alpha$-Trehalose, raffinose, L-sorbose, Dglucosamine, D-xylose, L-arabinose, D-arabinose, L-rhamnose, cellobiose, melibiose, lactose, melezitose, inulin, starch, erythritol, adonitol, dulcitol, D-mannitol, D-sorbitol, malic acid, methanol, ethanol, nitrate, nitrite, ethylamine and L-lysine are not assimilated. Growth on $50 \%$ glucose and $10 \% \mathrm{NaCl}$ is negative. Growth occurs on $5 \%$ $\mathrm{NaCl}$ and weakly in presence of $0.1 \%$ cycloheximide. Growth occurs at 25 and $4{ }^{\circ} \mathrm{C}$, but not at 37 or $42{ }^{\circ} \mathrm{C}$. No starch-like substance is produced. Urease hydrolysis and Diazonium blue B reaction are negative. Lipase activity is weak, whereas proteinase activity on casein agar is positive.

The type strain is LCF $1675^{\mathrm{T}}\left(=\mathrm{CBS} 11859^{\mathrm{T}}\right)$, isolated from lentisk rhizosphere in the island of Sardinia, near the Piscinas dunes $\left(39^{\circ} 32^{\prime} 30^{\prime \prime} \mathrm{N} 8^{\circ} 27^{\prime} 37^{\prime \prime} \mathrm{E}, 33 \mathrm{~m}\right.$ above sea-level).

\section{Acknowledgements}

This project was partly funded by the Italian Ministry of Agriculture (MiPAF) within the project MARKERINBIO; the same project supported L.A. L.R. was supported by a $\mathrm{PhD}$ grant from the Italian Ministry of Education. The authors dedicate this article to Professor Fabrizio Fatichenti, who spent 24 years of his career at the University of Sassari in Sardinia.

\section{References}

Barazani, O. \& Golan-Goldhirsh, A. (2009). Salt-driven interactions between Pistacia lentiscus and Salsola inermis. Environ Sci Pollut Res Int 16, 855-861.

Bolano, A., Stinchi, S., Preziosi, R., Bistoni, F., Allegrucci, M., Baldelli, F., Martini, A. \& Cardinali, G. (2001). Rapid methods to extract DNA and RNA from Cryptococcus neoformans. FEM Yeast Res 1, 221-224.

Capriotti, A. (1967). Saccharomyces servazzii n. sp. A new yeast from Finland soil. Ann Microbiol Enzimol 17, 79-84.

Cardinali, G., Bolano, A. \& Martini, A. (2001). A DNA extraction and purification method for several yeast genera. Ann Microbiol 51, 121-130.

Chen, R., Wei, S. C., Jiang, Y. M., Wang, Q. M. \& Bai, F. Y. (2010). Kazachstania taianensis sp. nov., a novel ascomycetous yeast species from orchard soil. Int J Syst Evol Microbiol 60, 1473-1476.
Drummond, A. J., Ashton, B., Cheung, M., Heled, J., Kearse, M., Moir, R., Stones-Havas, S., Thierer, T. \& Wilson, A. (2009). Geneious v4.8. Available from http://www.geneious.com.

Edgar, R. C. (2004). MUSCLE: a multiple sequence alignment method with reduced time and space complexity. BMC Bioinformatics 5, 113.

Felsenstein, J. (1985). Confidence limits on phylogenies: an approach using the bootstrap. Evolution 39, 783-791.

Ferreira, N., Belloch, C., Querol, A., Manzanares, P., Vallez, S. \& Santos, A. (2010). Yeast microflora isolated from brazilian cassava roots: taxonomical classification based on molecular identification. Curr Microbiol 60, 287-293.

Flahou, B., De Baere, T., Chiers, K., Pasmans, F., Haesebrouck, F. \& Ducatelle, R. (2010). Gastric infection with Kazachstania heterogenica influences the outcome of a Helicobacter suis infection in Mongolian gerbils. Helicobacter 15, 67-75.

Hong, S. G., Lee, K. H., Kwak, J. \& Bae, K. S. (2006). Diversity of yeasts associated with Panax ginseng. J Microbiol 44, 674-679.

Imanishi, Y., Ueda-Nishimura, K. \& Mikata, K. (2007). Two new species of Kazachstania that form ascospores connected by a belt-like intersporal body: Kazachstania zonata and Kazachstania gamospora. FEMS Yeast Res 7, 330-338.

Inácio, J., Pereira, P., de Carvalho, M., Fonseca, A., Amaral-Collaço, M. T. \& Spencer-Martins, I. (2002). Estimation and diversity of phylloplane mycobiota on selected plants in a Mediterranean-type ecosystem in Portugal. Microb Ecol 44, 344-353.

Inácio, J., Ludwig, W., Spencer-Martins, I. \& Fonseca, A. (2010). Assessment of phylloplane yeasts on selected Mediterranean plants by FISH with group- and species-specific oligonucleotide probes. FEMS Microbiol Ecol 71, 61-72.

Kurtzman, C. P. \& Fell, J. W. (editors) (1998). The Yeasts: a Taxonomic Study, 4th edn. Amsterdam: Elsevier.

Kurtzman, C. P. \& Robnett, C. J. (1998). Identification and phylogeny of ascomycetous yeasts from analysis of nuclear large subunit (26S) ribosomal DNA partial sequences. Antonie van Leeuwenhoek 73, 331371.

Kurtzman, C. P. \& Robnett, C. J. (2003). Phylogenetic relationships among yeasts of the 'Saccharomyces complex' determined from multigene sequence analyses. FEMS Yeast Res 3, 417-432.

Lee, C. F., Liu, C. H., Young, S. S. \& Chang, K. S. (2008). Kazachstania jiainicus sp. nov., an ascomycetous yeast species isolated from soil in Taiwan. FEMS Yeast Res 8, 114-118.

Lee, C. F., Yao, C. H., Liu, Y. R., Young, S. S. \& Chang, K. S. (2009). Kazachstania wufongensis sp. nov., an ascosporogenous yeast isolated from soil in Taiwan. Antonie van Leeuwenhoek 95, 335341.

Limtong, S., Yongmanitchai, W., Tun, M. M., Kawasaki, H. \& Seki, T. (2007). Kazachstania siamensis sp. nov., an ascomycetous yeast species from forest soil in Thailand. Int J Syst Evol Microbiol 57, 419422.

Lu, H. Z., Cai, Y., Wu, Z. W., Jia, J. H. \& Bai, F. Y. (2004). Kazachstania aerobia sp. nov., an ascomycetous yeast species from aerobically deteriorating corn silage. Int J Syst Evol Microbiol 54, 2431-2435.

Mikata, K., Ueda-Nishimura, K. \& Hisatomi, T. (2001). Three new species of Saccharomyces sensu lato van der Walt from Yaku Island in Japan: Saccharomyces naganishii sp. nov., Saccharomyces humaticus sp. nov. and Saccharomyces yakushimaensis sp. nov. Int J Syst Evol Microbiol 51, 2189-2198.

Naumov, G. I., Naumova, E. S. \& Korhola, M. (1995). Karyotyping relationships among species of Saccharomyces sensu lato: S. castellii, S. dairensis, S. unisporus, and S. servazzii. Syst Appl Microbiol 18, 103108. 
Nisiotou, A. A. \& Nychas, G. J. (2008). Kazachstania hellenica sp. nov., a novel ascomycetous yeast from a Botrytis-affected grape must fermentation. Int J Syst Evol Microbiol 58, 1263-1267.

O'Donnell, K. (1993). Fusarium and its near relatives. In The Fungal Holomorph: Mitotic, Meiotic and Pleomorphic Speciation in Fungal Systematics, pp. 225-233. Edited by D. R. Reynolds \& J. W. Taylor. Wallingford: $\mathrm{CAB}$ International.

Tamura, K. \& Nei, M. (1993). Estimation of the number of nucleotide substitutions in the control region of mitochondrial DNA in humans and chimpanzees. Mol Biol Evol 10, 512-526.

Tamura, K., Nei, M. \& Kumar, S. (2004). Prospects for inferring very large phylogenies by using the neighbor-joining method. Proc Natl Acad Sci U S A 101, 11030-11035.

Tamura, K., Dudley, J., Nei, M. \& Kumar, S. (2007). MEGA4: molecular evolutionary genetics analysis (MEGA) software version 4.0. Mol Biol Evol 24, 1596-1599.
Von Arx, J. A., Rodrigues de Miranda, L., Smith, M. T. \& Yarrow, D. (1977). The Genera of Yeasts and Yeast-Like Fungi, vol. 14. Utrecht NL: CBS.

Weber, G., Spaaij, F. \& van der Walt, J. P. (1992). Kluyveromyces piceae sp. nov., a new yeast species isolated from the rhizosphere of Picea abies (L.) Karst. Antonie van Leeuwenhoek 62, 239-244.

Wu, Z.-W. \& Bai, F.-Y. (2005). Kazachstania aquatica sp. nov. and Kazachstania solicola sp. nov., novel ascomycetous yeast species. Int $J$ Syst Evol Microbiol 55, 2219-2224.

Yarrow, D. (1998). Methods for the isolation, maintenance and identification of yeasts. In The Yeasts: a Taxonomic Study, 4th edn, pp. 77-100. Edited by C. P. Kurtzman \& J. W. Fell. Amsterdam: Elsevier.

Zubkova, R. D. (1971). Genus novum Saccharomycetacearum e Kazachstania. Bot Mater Gerb Inst Bot Akad Kazakh SSR 7, 53-56 (in Russian). 